\title{
Sexual Health, Suicidal Ideation and weight changes in Cancer patients during Chemotherapy and Radiotherapy Treatment
}

\author{
Article by Kavita Gupta \\ Ph.D. Clinical Research, Texila American University, India \\ E-mail: 16kavitagupta@texilaconnect.com
}

\begin{abstract}
Background: During chemotherapy or radiotherapy sessions, cancer patients often go through a series of physical, psychological, social and environmental changes that affects the QOL of the patients. While assessing for the anxiety and depression scores affecting the QOL, maximum of the patients left the question of sexual activity, suicidal ideation and weight issues unanswered.

Objectives: The present paper focused on the issue of sexual activity, suicidal ideation, and weight changes during chemotherapy or radiotherapy sessions while determining the anxiety and depression scores for QOL of cancer patients during the treatment regimen.

Methods: It was a cross-sectional, descriptive, hospital based evaluation study. Total duration of the study was 5 months (December 2015- April 2016), conducted in Medical and Radiation Oncology department of Dr. B.L. Kapur Memorial Hospital, New Delhi, India. A convenience sample of 60 patients (Chemotherapy group $(n=30)$ and Radiotherapy group $(n=30))$ with cancer was selected. Data was obtained through direct interview, using validated Psychological intervention tool in the form of Questionnaire: WHOQOL-Bref Questionnaire, Zung Self-Rating Anxiety scale and Zung Self-Rating Depression scale, which was further managed through a statistical program, using appropriate statistical tests.

Results: A total of 60 cancer patients were included in the study in which Chemotherapy group consisted of 30n cancer patients and Radiotherapy group consisted of 30n cancer patients. In the study, 6(20\%) were males and 24(80\%) were females in the chemotherapy group, and, 15(50\%) were males and $15(50 \%)$ were females in the radiotherapy group. Majority of the patients 32(53.34\%) were in the age range of 46-60 years.

Conclusion: It could be concluded from the present study that in Indian scenario, cancer patients felt sexual activity and suicidal ideation as a social stigma which is further accompanied by hesitation. Moreover, maximum patients observed stable weight and some patients observed increase in weight during chemotherapy sessions.
\end{abstract}

Keywords: Cancer, Chemotherapy, Radiotherapy, Quality of Life, missing values, sexuality, suicidal ideation, weight increased, weight stability.
Abbreviations
QOL : Quality of life
QLQ : Quality life Questionnaire
WHOQOL-Bref : World Health Organization Quality of life assessment-a short brief version
ZSAS $\quad$ : Zung Self-Rating Anxiety scale
ZSDS $\quad$ : Zung Self-Rating Depression scale 
Texila International Journal of Clinical Research

Volume 3, Issue 2, Dec 2016

$\begin{array}{ll}\text { CT } & : \text { Chemotherapy Treatment } \\ \text { RT } & : \text { Radiotherapy Treatment } \\ \text { DOM } & : \text { Domain } \\ \text { TPA } & : \text { Third Party Administrator } \\ \text { FNAC } & : \text { Sine needle aspiration cytology } \\ \text { SD } & \end{array}$

\section{Introduction}

It is important to study QOL aspects in cancer patients because of chronic nature of the disease, regular follow-up by the patient, different types of treatments given (radiation, surgery and chemotherapy), influence on sexual life, suicidal ideation and self-identity of cancer patients ${ }^{[1]}$. Cancer treatment, especially chemotherapy, creates changes in the patient's body that affects sexual desire, sexual functioning, and emotional relationships ${ }^{[2]}$. Human sexuality is an important aspect of well-being that could be altered significantly by cancer and its related treatment ${ }^{[2]}$. Because cancer is not considered a chronic illness until recently, sexuality, suicidal ideation, and weight changes issue usually is not addressed by nurses or other health care professionals ${ }^{[3]}$. Although healthy women also experience physiological changes leading to menopause, these changes occurred gradually leaving them sexually active 5 to 10 years longer and with fewer problems in sexual functioning ${ }^{[2]}$. Studies showed that breast cancer patients experienced sexual problems soon after treatment, and continue in follow-up ${ }^{[2]}$. Research also described the normal decline in sexuality among healthy men and women as they age ${ }^{\text {[2] }}$. Furthermore, relationship problems occurred when couples experienced sexual problems, sometimes threatening their attachment ${ }^{[2]}$. These problems could be anticipated and addressed through the physician's communication with their patient ${ }^{[2]}$. Other solutions included effective psychologic and emotional counseling and pharmaceutical and over the counter assistance for dealing with the related issues $^{[2]}$. It is essential that nurses and healthcare professionals have the appropriate knowledge, skill, and attitudes to address the oncology patient's concerns about sexuality effectively ${ }^{[3]}$. Using Annon's PLISSIT (permission, limited information, specific suggestions, and intensive therapy) model of sexual assessment, the healthcare professionals could learn how to assess a patient's sexual concerns, thus breaking the silence ${ }^{[3]}$.

\section{Aims}

The main objectives of the present study was:

i. To evaluate and determine the missing values of sexual health, suicidal ideation, and weight changes in the WHOQOL-Bref, Zung Self-rating Anxiety Scale (ZSAS) that affected overall QOL in cancer patients during Chemotherapy or Radiotherapy treatment regimen.

\section{Patients and methods}

The proposed study was conducted in accordance and adherence to the Ethical Guidelines and Procedures. Special care of the potential risks due to emotional distress was taken care of so that the dignity of the subject was not harmed. The authorized Ethical approval from the IRB and Ethical committee of Dr. B.L. Kapur Memorial Hospital, New Delhi, with Ref. No.: IRB/AARCE/5/DEC/2015/1, dated December $7^{\text {th }}$, 2015, was obtained to carry out the research study. Thereafter, the patients and their caregivers were approached in the inpatient as well as, outpatient clinic, where the purpose of the study was explained and they were invited to participate. Patients who agreed to 
participate were asked to sign an Informed Consent Form followed by the implementation of the Structured and Validatedinstrumental tool of WHOQOL-Bref, Zung Self-Rating Anxiety Scale (ZSAS), and Zung Self-Rating Depression Scale (ZSDS) in the form of questionnaire which lasted for approximately 25-60 minutes. The RESEARCH DESIGN of the proposed approved study protocol included 30n cancer patients undergoing Chemotherapy Treatment and 30n cancer patients undergoing Radiotherapy Treatment session. The inclusion criteria for the approved study were the patients with Breast cancer, sub-sites of head and neck tumors (e.g., nasopharyngeal, thyroid cancer, and parotidtumors), aged 18years or older, Clinically diagnosed and confirmed by biopsy or FNAC, Undergoing/during the treatment sessions ( $\geq 2$ cycles and $\leq 6$ for Chemotherapy treatment, and $\geq 10$ cycles and $\leq 30$ cycles for Radiotherapy treatment, Voluntarily agreed to join the study, and aware of diagnosis and predicted prognosis. However, the study excluded patients with Inadequate clinical condition (ambulatory and terminally ill patients) who were unable to respond to an interview, had difficulty in understanding the questionnaire or communicating, were serious and didn't give consent, had a history of psychiatric disorder. Moreover, the study did not include the dosage of chemotherapy drugs and irradiation treatment. Eligible patients were identified through an institutional database or by referring physicians and were approached at their simulation appointment.

\section{Results}

\section{(a) Data collection}

Treatment-related symptoms were assessed by using a series of interviews through standard questionnaires of WHOQOL-Bref, the core questionnaire, followed by Zung Self-Rating Anxiety Scale (ZSAS) and Zung Self Rating Depression Scale (ZSDS) Questionnaires. These questionnaires have been proven to have good validity and reliability properties, cross-culturally accepted instrument to measure Quality of Life in cancer patients and are publicly available for scholar research purposes ${ }^{[5,6,7]}$. The questionnaire was provided in a language that the patient could understand easily (English / Hindi) followed by face-to-face interview of the patient who was either undergoing chemotherapy or radiotherapy treatment sessions.

Parts of the Record Card:

i. Personal information form:This first part contained patient information. The form was prepared, based on the literature. It contained age, gender, qualification, marital status, family type, Occupation, data on financial income and site of tumor location ${ }^{[5]}$.

ii. WHOQOL-Bref Questionnaire: This is an abbreviated version of the instrument WHOQOL-100. It consisted of 26 questions, being two about quality of life in general and other 24 representing each of the facets that made up the original instrument ${ }^{[5]}$. The questions were organized in 4 domains:

a. Physical domain (DOM1): It included7 questions pertaining to sleep, energy, mobility, the extent to which pain prevents performance of necessary tasks, the need for medical treatment to function in daily life, level of satisfaction with their capacity for work ${ }^{[5]}$.

b. Psychological domain (DOM2): It included6 questions pertaining to the ability to concentrate, selfesteem, body image, spirituality i.e. the extent to which they feel their life is meaningful, the frequency of positive or negative feelings i.e. blue mood, despair, anxiety, depression ${ }^{[5]}$.

c. Social domain (DOM3): It included 3 questions pertaining to satisfaction with personal relationships, social support systems and sexual satisfaction ${ }^{[5]}$.

d. Environmental domain (DOM4): It included 8 questions related to safety and security, home and physical environment satisfaction, finance i.e. does the respondent have enough money to meet their needs, health/social care availability, information and leisure activity accessibility and transportation satisfaction ${ }^{[5]}$.

Equations for computing domain raw scores:

Domain 1 (Physical) score $=(6-\mathrm{Q} 3)+(6-\mathrm{Q} 4)+\mathrm{Q} 5+\mathrm{Q} 6+\mathrm{Q} 7+\mathrm{Q} 8+\mathrm{Q} 9$

Domain 2 (Psychological) score = Q10 + Q11 + Q12 + Q13 + Q14 + (6-Q15) 
Texila International Journal of Clinical Research

Volume 3, Issue 2, Dec 2016

Domain 3 (Social) score $=$ Q16 + Q17 + Q18

Domain 4 (Environmental) score = Q19 + Q20 + Q21 + Q22 + Q23 + Q24 + Q25 + Q26 ${ }^{[5]}$.

In addition to the 4 domains, the WHOQOL-Bref included two stand-alone questions, one pertaining to the respondents' rated QOL, and one related to their Satisfaction with Health were analyzed separately ${ }^{[5]}$. The score of each question ranged from 1 to 5 on a 5 point likert scale and higher scores indicated a better evaluation. Raw scores of the respective domains were then transformed from 0-100 with the lowest score of zero and the highest score of 100according to the accepted guidelines ${ }^{[5]}$.

iii.ZSAS: Zung Self-Rating Anxiety scale quality life questionnaire is a likert scale format (scoring on 1 to 4 scale) that was built by a psychiatrist, William W. K. Zung to measure the rate of anxiety. The scale consisted of 20 self-reported items with 15 questions of increasing anxiety level and 5 questions of decreasing anxiety level (Q. no. 5, 9, 13, 17, 19) ${ }^{[6]}$. Scores for each question ranged from 1 to 4 and higher scores indicated severe anxiety level. The raw scores were counted up and multiplied by 1.25 to reach a standardized score, according to the instructions that accompanied the scale ${ }^{[6]}$. The ZSAS Index score followed the crierion: Normal Range (20-44); Mild to Moderate Anxiety level (45-59); Marked to Severe Anxiety level (60-74); Extreme Anxiety level (75-80) ${ }^{[6]}$.

iv.ZSDS: Zung Self-Rating Depression scale quality life questionnaire is also a 20 items short selfadministered survey that was designed by William W. K. Zung to assess the level of four common characteristics of depression for patients: the pervasive effect, the physiological equivalents, other disturbances, and psychomotor activities. There were ten positively worded and ten negatively worded questions. Each question was scored on a scale of 1-4 (a little of the time, some of the time, good part of the time, most of the time) ${ }^{[7]}$. The higher scores indicated severe depression level. The raw scores were counted up and multiplied by 1.25 to reach a standardized score, according to the instructions that accompanied the scale ${ }^{[7]}$. The ZSDS Index score followed the crierion: Normal Range $(<50)$; Mild Depression level $(<60)$; Moderate Depression level $(<70)$; Extreme Depression level $(>70){ }^{[7]}$.

\section{(b) Statistical analyses}

The database and statistical analysis was performed by using SPSS v.17 software. The independent variables analyzed were Socio-demographic characteristics (sex/gender, age, education level, marital status, employment type, income level (per annum), job background, local residence), Clinical characteristics (smoking habit, drinking habit, tobacco use, health insurance, tumor type \& location, metastasis involved, corresponding cycle number for both chemotherapy and radiotherapy treatment); Anxiety and Depression of the patients as assessed by ZSAS and ZSDS respectively. The dependent variables included: subscale and overall QOL scores, and Health satisfaction as measured by WHOQOLBref Questionnaire (Tool/instrument). Descriptive statistics computation techniques were applied to the discrete and continuous data. Measures such as mean, standard deviation, minimum and maximum range were developed from the continuous data. Relative frequency was calculated for discrete data. Mean with Standard deviation (SD) was used to summarize the age of patients. Chi-square test was performed to assess the effect of different sociodemographic factors and clinical characteristics on the QOL of the cancer patients. Student's $t$-test was used to compare sample means for study variables (anxiety, depression and QOL). Bivariate analysis was performed to assess the predictors of QOL. Based on the survey/ research, Pearson Correlation coefficient test denoted by $r$ was calculated to assess the particular characteristic symptomatic function of anxiety and depression instrument that significantly affected the QOL domains, i.e., either positively or negatively. Paired t-test was used to compare difference between score means of different domains. A $p$-value $<0.05$ was considered as statistical significant. 


\section{Socio-Demographic characteristics of the patients}

Table 1. Socio-demographic characteristics in the form of Frequency and percentage of variables of the patients and correlation in the two groups, i.e., Chemotherapy and Radiotherapy

(All tests were performed using Pearson $\chi 2$ test for association analysis)

\begin{tabular}{|c|c|c|c|c|c|c|}
\hline \multirow[t]{2}{*}{ S.No } & \multirow[t]{2}{*}{ Variables } & \multirow[t]{2}{*}{ Parameters } & \multicolumn{2}{|c|}{ Chemotherapy } & \multicolumn{2}{|c|}{ Radiotherapy } \\
\hline & & & $\begin{array}{l}\text { Frequency } \\
\text { (n) }\end{array}$ & $\begin{array}{l}\text { Percentage } \\
\text { (\%) }\end{array}$ & $\begin{array}{l}\text { Frequency } \\
\text { (n) }\end{array}$ & $\begin{array}{l}\text { Percentage } \\
\text { (\%) }\end{array}$ \\
\hline 1. & Gender & $\begin{array}{l}\text { a. Male } \\
\text { b. Female }\end{array}$ & $\begin{array}{l}6 \\
24\end{array}$ & $\begin{array}{l}20.0 \% \\
80.0 \%\end{array}$ & $\begin{array}{l}15 \\
15\end{array}$ & $\begin{array}{l}50.0 \% \\
50.0 \%\end{array}$ \\
\hline 2. & Age & $\begin{array}{l}\text { a. } 18-30 \text { years } \\
\text { b. } 30 \\
\text { c. } 46 \\
\text { d. } 60\end{array}$ & $\begin{array}{l}5 \\
17 \\
8 \\
\end{array}$ & $\begin{array}{l}16.7 \% \\
56.7 \% \\
26.7 \% \\
\end{array}$ & $\begin{array}{l}6 \\
15 \\
9 \\
\end{array}$ & $\begin{array}{l}20.0 \% \\
50.0 \% \\
30.0 \% \\
\end{array}$ \\
\hline 3. & $\begin{array}{l}\text { Marital } \\
\text { status }\end{array}$ & $\begin{array}{l}\text { a. Unmarried } \\
\text { b. Married } \\
\text { c. Widow } \\
\text { d. Divorced/ } \\
\quad \text { Legally } \\
\text { separated } \\
\text { e. Others }\end{array}$ & 30 & $100.0 \%$ & $\begin{array}{l}1 \\
28 \\
1\end{array}$ & $\begin{array}{l}3.3 \% \\
93.3 \% \\
3.3 \%\end{array}$ \\
\hline 4. & $\begin{array}{l}\text { Educational } \\
\text { status }\end{array}$ & $\begin{array}{l}\text { a. Illiterate } \\
\text { b. Literate }\end{array}$ & 1 & $3.3 \%$ & 2 & $6.7 \%$ \\
\hline & & $\begin{array}{l}\text { i. Primary } \\
\text { ii. Secondary } \\
\text { iii.Tertiary }\end{array}$ & $\begin{array}{l}4 \\
10 \\
15\end{array}$ & $\begin{array}{l}13.3 \% \\
33.3 \% \\
50.0 \%\end{array}$ & $\begin{array}{l}5 \\
11 \\
12\end{array}$ & $\begin{array}{l}16.7 \% \\
36.7 \% \\
40.0 \%\end{array}$ \\
\hline 5. & Occupation & $\begin{array}{l}\text { a. Service } \\
\text { b. Business } \\
\text { c. Housewife } \\
\text { d. Freelancers } \\
\text { e. Pensioners } \\
\text { f. Domestic } \\
\quad \text { duties } \\
\text { g. Cultivation }\end{array}$ & $\begin{array}{l}3 \\
3 \\
21 \\
3\end{array}$ & $\begin{array}{l}10.0 \% \\
10.0 \% \\
70.0 \% \\
10.0 \%\end{array}$ & $\begin{array}{l}10 \\
2 \\
11 \\
1 \\
4 \\
1 \\
1\end{array}$ & $\begin{array}{l}33.3 \% \\
6.7 \% \\
36.7 \% \\
3.3 \% \\
13.3 \% \\
3.3 \% \\
3.3 \%\end{array}$ \\
\hline 6. & $\begin{array}{l}\text { Type of } \\
\text { family }\end{array}$ & $\begin{array}{l}\text { a. Nuclear } \\
\text { b. Joint }\end{array}$ & $\begin{array}{l}16 \\
14\end{array}$ & $\begin{array}{l}53.3 \% \\
46.7 \%\end{array}$ & $\begin{array}{l}9 \\
21\end{array}$ & $\begin{array}{l}30.0 \% \\
70.0 \%\end{array}$ \\
\hline 7. & Cohabitants & $\begin{array}{l}\text { a. Living } \\
\text { alone } \\
\text { b. Living with } \\
\text { partner } \\
\text { c. Living with } \\
\text { partner and } \\
\text { children }\end{array}$ & $\begin{array}{l}15 \\
1\end{array}$ & $\begin{array}{l}50.0 \% \\
3.3 \%\end{array}$ & $\begin{array}{l}4 \\
5\end{array}$ & $\begin{array}{l}13.3 \% \\
16.67 \%\end{array}$ \\
\hline
\end{tabular}


Texila International Journal of Clinical Research

Volume 3, Issue 2, Dec 2016

\begin{tabular}{|c|c|c|c|c|c|c|}
\hline & & $\begin{array}{l}\text { d. Living with } \\
\text { children }\end{array}$ & 14 & $46.7 \%$ & 21 & $70.0 \%$ \\
\hline 8. & $\begin{array}{l}\text { Annual } \\
\text { income }\end{array}$ & $\begin{array}{l}\text { a. NA } \\
\text { b. } \leq 20 \\
\text { c. } 20 \\
\text { d. } 30 \\
\text { e. } 41 \\
\text { f. } \geq 84\end{array}$ & 22 & $73.3 \%$ & 11 & $63.3 \%$ \\
\hline 9. & $\begin{array}{l}\text { Place of } \\
\text { residence }\end{array}$ & $\begin{array}{l}\text { a. Small town } \\
\text { b. Big town }\end{array}$ & $\begin{array}{l}1 \\
29\end{array}$ & $\begin{array}{l}3.3 \% \\
96.7 \%\end{array}$ & $\begin{array}{l}8 \\
22\end{array}$ & $\begin{array}{l}26.7 \% \\
73.3 \%\end{array}$ \\
\hline
\end{tabular}

Clinical characteristics of the patients

Table 2. Clinicalcharacteristics in the form of Frequency and percentage of variables of the patients and correlation in the two groups, i.e., Chemotherapy or Radiotherapy

(All tests were performed using Pearson $\chi 2$ test for association analysis).

\begin{tabular}{|c|c|c|c|c|c|c|}
\hline \multirow[t]{2}{*}{ S.No. } & \multirow[t]{2}{*}{ Variables } & \multirow[t]{2}{*}{ Parameters } & \multicolumn{2}{|c|}{ Chemotherapy } & \multicolumn{2}{|c|}{ Radiotherapy } \\
\hline & & & $\begin{array}{l}\text { Frequency } \\
\text { (n) }\end{array}$ & $\begin{array}{l}\text { Percentage } \\
\text { (\%) }\end{array}$ & $\begin{array}{l}\text { Frequency } \\
\text { (n) }\end{array}$ & $\begin{array}{l}\text { Percentage } \\
(\%)\end{array}$ \\
\hline 1. & $\begin{array}{l}\text { Smoking } \\
\text { habit }\end{array}$ & $\begin{array}{l}\text { a. Non-smoker } \\
\text { b. Ex-smoker }\end{array}$ & $\begin{array}{l}27 \\
3 \\
\end{array}$ & $\begin{array}{l}90.0 \% \\
10.0 \% \\
\end{array}$ & $\begin{array}{l}27 \\
4 \\
\end{array}$ & $\begin{array}{l}90.0 \% \\
10.0 \% \\
\end{array}$ \\
\hline 2. & $\begin{array}{l}\text { Drinking } \\
\text { habit }\end{array}$ & $\begin{array}{l}\text { a. Non-drinker } \\
\text { b. Ex-drinker }\end{array}$ & 30 & $100.0 \%$ & $\begin{array}{l}26 \\
4 \\
\end{array}$ & $\begin{array}{l}86.7 \% \\
13.3 \% \\
\end{array}$ \\
\hline 3. & $\begin{array}{l}\text { Tobacco } \\
\text { use }\end{array}$ & $\begin{array}{l}\text { a. Yes } \\
\text { b. No }\end{array}$ & $\begin{array}{l}1 \\
29 \\
\end{array}$ & $\begin{array}{l}3.3 \% \\
96.7 \% \\
\end{array}$ & $\begin{array}{l}7 \\
23 \\
\end{array}$ & $\begin{array}{l}23.3 \% \\
76.7 \% \\
\end{array}$ \\
\hline 4. & $\begin{array}{l}\text { Health } \\
\text { insurance }\end{array}$ & $\begin{array}{l}\text { a. Yes } \\
\text { b. No }\end{array}$ & $\begin{array}{l}23 \\
7 \\
\end{array}$ & $\begin{array}{l}76.7 \% \\
23.3 \% \\
\end{array}$ & $\begin{array}{l}19 \\
11\end{array}$ & $\begin{array}{l}63.3 \% \\
36.7 \% \\
\end{array}$ \\
\hline 5. & $\begin{array}{l}\text { Type of } \\
\text { health } \\
\text { insurance }\end{array}$ & $\begin{array}{l}\text { a. Government } \\
\text { medically } \\
\text { insured } \\
\text { b. TPA } \\
\text { c. Cash }\end{array}$ & $\begin{array}{l}10 \\
13 \\
7\end{array}$ & $\begin{array}{l}33.3 \% \\
43.3 \% \\
23.3 \%\end{array}$ & $\begin{array}{l}12 \\
7 \\
11\end{array}$ & $\begin{array}{l}40.0 \% \\
23.3 \% \\
36.7 \%\end{array}$ \\
\hline 6. & $\begin{array}{l}\text { Support by } \\
\text { charity } \\
\text { organizatio } \\
n\end{array}$ & $\begin{array}{l}\text { a. Yes } \\
\text { b. No }\end{array}$ & 30 & $100.0 \%$ & 30 & $100 \%$ \\
\hline 7. & $\begin{array}{l}\text { Cancer } \\
\text { tumor } \\
\text { location }\end{array}$ & a. Ca Breast & 23 & $76.7 \%$ & 10 & $33.3 \%$ \\
\hline
\end{tabular}


Texila International Journal of Clinical Research Volume 3, Issue 2, Dec 2016

\begin{tabular}{|c|c|c|c|c|c|c|}
\hline & & $\begin{array}{l}\text { b. Ca Head } \\
\text { c. Ca Neck }\end{array}$ & $\begin{array}{l}1 \\
6\end{array}$ & $\begin{array}{l}3.3 \% \\
20.0 \%\end{array}$ & $\begin{array}{l}5 \\
15\end{array}$ & $\begin{array}{l}16.7 \% \\
50.0 \%\end{array}$ \\
\hline 8. & $\begin{array}{l}\text { Disease } \\
\text { acceptance }\end{array}$ & $\begin{array}{l}\text { a. Yes } \\
\text { b. No }\end{array}$ & $\begin{array}{l}23 \\
7 \\
\end{array}$ & $\begin{array}{l}76.7 \% \\
23.3 \% \\
\end{array}$ & $\begin{array}{l}15 \\
15 \\
\end{array}$ & $\begin{array}{l}50.0 \% \\
50.0 \% \\
\end{array}$ \\
\hline 9. & $\begin{array}{l}\text { Reproductiv } \\
\text { e age of } \\
\text { women }\end{array}$ & $\begin{array}{l}\text { a. Pre- } \\
\text { menopausal } \\
\text { b. Menopausal }\end{array}$ & $\begin{array}{l}10 \\
14 \\
\end{array}$ & $\begin{array}{l}33.3 \% \\
46.7 \% \\
\end{array}$ & $\begin{array}{l}9 \\
6 \\
6\end{array}$ & $\begin{array}{l}30.0 \% \\
20.0 \% \\
\end{array}$ \\
\hline 10. & Cancer type & $\begin{array}{l}\text { a. Primary } \\
\text { cancer } \\
\text { b. Recurrent } \\
\text { cancer } \\
\end{array}$ & 30 & $100.0 \%$ & 30 & $100.0 \%$ \\
\hline 11. & $\begin{array}{l}\text { Co- } \\
\text { existence of } \\
\text { metastasis }\end{array}$ & $\begin{array}{l}\text { a. Yes } \\
\text { b. No }\end{array}$ & $\begin{array}{l}8 \\
22\end{array}$ & $\begin{array}{l}26.7 \% \\
73.4 \%\end{array}$ & 30 & $100.0 \%$ \\
\hline 12. & $\begin{array}{l}\text { Chemothera } \\
\text { py's cycle } \\
\text { during the } \\
\text { interview of } \\
\text { QLQ }\end{array}$ & $\begin{array}{l}\text { a. } 1^{\text {st }} \\
\text { b. } 2^{\text {nd }} \\
\text { c. } 3^{\text {rd }} \\
\text { d. } 4^{\text {th }} \\
\text { e. } 5^{\text {th }} \\
\text { f. } 6^{\text {th }}\end{array}$ & $\begin{array}{l}2 \\
15 \\
6 \\
6 \\
1\end{array}$ & $\begin{array}{l}6.7 \% \\
50.0 \% \\
20.0 \% \\
20.0 \% \\
3.3 \%\end{array}$ & & \\
\hline 13 & $\begin{array}{l}\text { Radiotherap } \\
\text { y's cycle } \\
\text { during the } \\
\text { interview of } \\
\text { QLQ }\end{array}$ & $\begin{array}{l}\text { a. } 10^{\text {th }}-15^{\text {th }} \\
\text { b. } 16^{\text {th }}-20^{\text {th }} \\
\text { c. } 21^{\text {st }}-25^{\text {th }} \\
\text { d. } 26^{\text {th }} 30^{\text {th }}\end{array}$ & & & $\begin{array}{l}21 \\
3 \\
1 \\
\end{array}$ & $\begin{array}{l}16.7 \% \\
\\
\\
\\
70.0 \% \\
10.0 \% \\
3.3 \% \\
\end{array}$ \\
\hline
\end{tabular}


Texila International Journal of Clinical Research

Volume 3, Issue 2, Dec 2016

Response pattern and missing items for each item in WHOQOL Bref, ZSAS, and ZSDS in both Chemotherapy $(n=30)$ and Radiotherapy $(n=30)$ group

Table 3. Missing values while assessing for QOL of cancer patients for chemotherapy group $(\mathrm{n}=30)$ and radiotherapy group $(\mathrm{n}=30)$.

\begin{tabular}{|l|l|l|l|l|l|l|}
\hline \multirow{2}{*}{ Item number } & \multicolumn{2}{l|}{ Chemotherapy } & \multicolumn{2}{l|}{ Radiotherapy } \\
\cline { 2 - 7 } & $\begin{array}{l}\text { Missingn } \\
(\%)\end{array}$ & $\begin{array}{l}\text { Mean } \\
\text { Score }\end{array}$ & SD & $\begin{array}{l}\text { Missingn } \\
(\%)\end{array}$ & $\begin{array}{l}\text { Mean } \\
\text { Score }\end{array}$ & SD \\
\hline $\begin{array}{l}\text { WHOQOL-BREF Scale: } \\
\text { Social Domain }\end{array}$ & & & & & & \\
Q 18. Sexual Activity & $30(100 \%)$ & 0.00 & 0.00 & $28(93.3 \%)$ & 0.06 & 0.25 \\
\hline ZSDS Scale: & & & & & & \\
Q 6. Sexual Activity & $30(100 \%)$ & 0.00 & 0.00 & $30(100 \%)$ & 0.00 & 0.00 \\
Q 7. Weight Loss & $14(46.7 \%)$ & 3.18 & 1.08 & 0.00 & 0.00 & 0.00 \\
Q 19. Suicidal Ideation & $30(100 \%)$ & 0.00 & 0.00 & $29(96.7 \%)$ & 1.00 & \\
\hline ZSDS Scale *: & & & & & & \\
\hline Q 7. Weight Constant* & $9(30.0 \%)$ & 2.55 & 1.23 & 0.00 & 0.00 & 0.00 \\
\hline Q 7. Weight Increased* & $5(16.66 \%)$ & 2.20 & 0.44 & 0.00 & 0.00 & 0.00 \\
\hline
\end{tabular}

The above table depicted that approximately all of the patients in both the treatment groups did not opt for the question of sexual activity and suicidal ideation. Moreover, weight loss was observed in 16 (53.33\%) patients undergoing chemotherapy; and 30(100\%) in the patients undergoing radiotherapy. On the other hand, 9(30.0\%) patients observed constant/stable weight, and 5(16.66\%) patients observed increase in weight during chemotherapy sessions.

\section{Discussion}

The present study determined that sexual activity factor in both the WHOQOL-Bref and ZSDS questionnaire was left unanswered by approximately most of the cancer patients in chemotherapy as well as, radiotherapy group. However, 2(93.3\%) patients with a mean score of 0.06 and SD of 0.25 answered the question of sexual activity in the social domain of WHOQOL-Bref but did not attempt it in the ZSDS questionnaire which depicted that this question was somewhere upsetting. Sexuality still seems to be tabooed among cancer patients, cancer patients being reluctant to talk about their sexual life, as they are afraid this might compromise their relationship. Older Polish people, especially over 65 years of age, regard questions pertaining to sexuality as "upsetting". On the other hand, it was observed that $9(2.55 \pm 1.23)$ patients observed constant weight and 5(2.20 \pm 0.44$)$ patients observed increase in weight during the chemotherapy sessions for cancer treatment. Moreover, 1(3.3\%) patient answered question of suicidal ideation of ZSDS in the radiotherapy group.

Women were found to be more affected during the treatment regimen and that too in the chemotherapy group ${ }^{[1]}$. Moreover, a woman plays vital central role in the family as a wife, sister, mother, and daughter, but there was some amount of negligence toward a woman's health in Indian families ${ }^{[1]}$. Some kind of blushing nature and negligence toward self-health was also there in Indian women as compared with the western population ${ }^{[1]}$. As per Montazeri study, when a woman developed breast cancer, all family members might develop some sort of illness ${ }^{[1]}$. If we look at the other parts, in western countries generally the decision about the health of the woman were taken by the patient herself but in India, spouse, family background and family income played an important role in the healthcare decision making for the patient ${ }^{[1]}$. Therefore, marital status of the patient might not be ignored as a factor affecting QOL ${ }^{[1]}$. During and after receiving treatment for cancer, men of all ages, with early and advanced diseases, will have concerns and questions about sexuality and sexual activity. It is common for men with different types of cancer to struggle with their body image; have less desire for sexual intimacy and/or have a 
change in their ability to achieve or maintain an erection during sexual activity or a change in orgasm or climax. Detection of cancer brings many changes in the life of a patient. For some of them it is a life changing experience ${ }^{[4]}$.

\section{Conclusion}

Sexual problems, suicidal ideation are a widespread concern among patients and survivors, but there was much variation in experiences of communication about sexual issues, and many patients did not receive the information they need from their oncology providers. There were large differences in sexual function between patients who did and did not ask providers about sexual problems. Sexual health had yet to be fully integrated into oncology care, even for cancers involving sex organs. On the hand, suicidal ideation feeling was increased due to increased depression. Therefore, this factor was also found to be ignored which needs attention. Moreover, some patients observed stable weight and some observed increase in their weight which needs to be further evaluated. Sexuality encompasses much more than sex; it includes the physical, psychological, emotional and social aspects of sex. In the real world, the present issues discuused means how the cancer patient see himself, how does his partner view him, how didhe date after cancer, how didhe fulfill his need for sexual relationships after cancer and so much more.

\section{Future directions}

a) The present missing values needs to be tested in the cancer patients that would attend either inpatient or outpatient department in the clinic for chemotherapy or radiotherapy treatment regimen.

\section{Limitations of the study}

a) Small number of sample size with single-centered study.

\section{Footnotes}

Author's Contribution: 1- acquisition of data; 2- analysis and interpretation of data; 3- drafting of the manuscript; 4- critical revision of the manuscript for important intellectual content; 5- statistical analysis; 6- administrative, technical and material supports.

Funding/Support: Self-funded.

\section{Acknowledgement}

The present study is a part of the research programme, “Assessment of Quality of Life of Adult Cancer Patients during inpatient Chemotherapy Treatment (CT), or outpatient Radiotherapy Treatment (RT) in a tertiary care hospital of New Delhi, India”. This research was supportedand assisted by at:

Department of Medical Oncology and Radiation Oncology, Dr. B.L. Kapur Memorial Hospital, New Delhi, India.

Under the Supervision of:

Dr. S. Hukku (H.O.D. of Radiation Oncology Department),

Dr. B.L. Kapur Memorial Hospital,

New Delhi, India.

Dr. Amit Agarwal (H.O.D. of Medical Oncology Department),

Dr. B.L. Kapur Memorial Hospital,

New Delhi, India.

Under the Guidance of:

Dr. Renita Bhamrah (Texila American University),

E-mail:darpreetrenita@gmail.com 
Texila International Journal of Clinical Research

Volume 3, Issue 2, Dec 2016

\section{References}

[1]. Deshpande, P. R., Sheriff, M. K., Nazir, A., Bommareddy, S., Tumkur, A., Naik, A. N. (2013). Patientreported quality of life outcomes in Indian breast cancer patients: Importance, review of the researches, determinants and future directions. J Can Res Ther, 9 (1), 11-6. Doi: 10.4103/0973-1482.110341

[2]. Fobair, Patricia, L.C.S.W., Spiegel, David. (2009). Concerns about Sexuality after Breast Cancer. The Cancer Journal, 15(1), 19-26. doi: 10.1097/PPO.0b013e31819587bb

[3]. http://journals.Iww.com/journalppo/Abstract/2009/02000/Concerns_About_Sexuality_After_Breast_Cancer.5. aspx

[4]. Hughes, Mary, K., M.S., R.N. (2000). Sexuality and the Cancer Survivor: A SILENT COEXISTENCE. Cancer Nursing, 23(6), 477-482.

[5]. http://journals.lww.com/cancernursingonline/Abstract/2000/12000/Sexuality_and_the_Cancer_Survivor_A_S ILENT.11.aspx

[6]. Sunderam, S., Haider, S., Kumar, M., Kashyap, V., Bhushan, S.S., S.J. (2015). Assessment of quality of life of cancer patients attending oncology clinic in a tertiary care hospital of Jharkhand, India. International Journal of Community Medicine and Public Health, 3(1), 281-286.

[7]. http://www.ejmanager.com/mnstemps/109/109-1446880098.pdf?t=1468312514

[8]. WHOQOL Group. (1998). Development of the World Health Organization WHOQOLBREF quality of life assessment. Psychol Med, 28:551-8.

[9]. Zung, W. W. K. (1971). A rating instrument for anxiety disorders. Psychosomatics, 12(6), 371-379. Available at: https://psychology-tools.com/zung-anxiety-scale/

[10]. Zung, W. W. K. (1965). A Self-Rating Depression Scale. (1965). Arch Gen Psychiatry, 12: 63-70. Available at: https://psychology-tools.com/zung-depression-scale/ 